\title{
THE MICROBIOLOGICAL AND SANITARY STATE OF SAND IN THE MUNICIPAL BATHING BEACH IN SZCZECIN
}

\author{
Kinga Zatoń', Magdalena Błaszak ${ }^{1}$ \\ 1 Department of Microbiology and Environmental Biotechnology, Faculty of Environmental Management and \\ Agriculture, West Pomeranian University of Technology in Szczecin, Słowackiego 17 Str., 71-434 Szczecin, \\ Poland, e-mail: mablaszak@zut.edu.pl
}

Received: 2015.08 .14 Accepted: 2015.10.06 Published: 2015.11.10

\begin{abstract}
Artificial beaches, i.e. places in the public sphere, are usually intended for recreation, located at water reservoirs, rivers, and their surface is naturally occurring or applied sand. The urban bathing beach located in Szczecin by the Deep lake has sand purchased and distributed on the beach by the Municipal Services Office in Szczecin (a few hundred ton). The beach is divided into sectors, a volleyball court is in one part, in the next section catering and sanitary facilities are located, and the remaining area is a place intended for sunbathing and playing games. The aim of the experiment was to assess the effects of different ways of using the beach on changes of microbiological properties of the sand. The tests were taken from the beach sand in May 2013 (first term examinations), and in September, after several months of use (the second term of examinations). The sand was collected near catering and sanitary sector (the first object) and from the area of the volleyball court (the second object), as well as the playground for children (the third object). The facilities were distanced from the shoreline of the lake by approx. 8 metres. The comparison included the number of heterotrophic bacteria, fungi and the detected presence of coliform bacteria, including Escherichia coli, bacteria of the genus Salmonella and eggs of intestinal parasites. In any of the objects, or the periods of time, eggs of intestinal parasites and bacteria of the genus Salmonella were detected. The presence of coliform bacteria including E. coli was found in the sand collected from a catering-sanitary zone, there was also the biggest number of bacteria and fungi. The number of heterotrophic bacteria and fungi was similar in samples of sand taken from the volleyball court and from the playground, in this sand there was no bacteria belonging to the $E$. coli species, although in several samples from the playground other bacteria belonging to the coliform genus were detected. To sum up, it is possible to state that the same sand used in various ways is gaining different microbiological characteristics. The values of the studied parameters differed significantly with regards to sand taken from the area of consumption, hygiene-sanitary activities and sand collected from the area of active leisure (the court and playground). These results indicate the need for a deliberate selection of location for sunbathing (children playing in the sand) away from the sites for culinary and sanitary purposes.
\end{abstract}

Keywords: beach, sand, sanitary condition, bacteria, fungi.

\section{INTRODUCTION}

Required sanitary examinations of water recreational activities concern the water itself, yet all sunbathers are in contact with sand rather than the water (Regulation of the Minister of Health from 8 April 2011. On the supervision over the qual- ity of bathing water and spots used for bathing). Beach sand is not subject to statutory sanitary inspections [Halliday and Gast 2011]. Monitoring of the sanitary quality of water includes the number of bacteria of the Enterococcus genus (e.g. Enterococcus faecalis), and the number of bacteria belonging to the species Escherichia coli. In 
both cases the presence of these bacteria in water is acceptable, however to the level which is not tantamount to the probability of the contamination of water with intestinal parasites. Indicator bacteria serve as a warning against infections with pathogens. Water polluted with faeces (which is equivalent to the presence of coliform bacteria in it) does not always contain pathogenic organisms (e.g. the bacteria of the genus Salmonella, Shigella) as not all people are the carriers of pathogens. There is a significant relationship between the number of coliform bacteria, and the amount of pathogenic microorganisms [Żakowska and Stobińska 2000; Delbeke et al. 2015]. The sand used in sandpits is not subject to sanitary control regardless of the degree of contamination, as it is not regulated by law. It is only the replacement of sand, at least twice a year (in practice the sand is replaced only once, at the beginning of the season) that is required. Sanitary Services are undertaking the studies of sand as a result of the conducted local actions of the cleanness or applications of alarmed citizens [Kukwa 2012; Młotkowska 2014]. Since beach sand is not subject to control, to assess its microbiological purity sanitary parameters concerning gardening bases in terms of sanitary horticultural substrates are used. Plant conditioners, with which humans (as similarly as with beach sand) are in contact during the recreation, are inspected for the presence of Salmonella bacteria and in terms of the presence of eggs of intestinal parasites (Regulation of the Minister of Agriculture and Rural Development of 18 June 2008. On the implementation of certain provisions of the Act on fertilizers and fertilization).
Yet in all cases of active recreation (recreation on the beach, playing in sandpits, gardening) humans are exposed to the risk of infection since a direct contact of material is taking place with the skin or the digestive system (especially in case of children). The legislator introduced a requirement of the substrates horticultural examining and other plant conditioners in terms of the presence of Salmonella bacteria and for the presence of intestinal parasites eggs. The presence of these organisms in any amount disqualifies the product. However, the presence of the bacteria from the Enterobacteriaceae family to the level of 1 thousand CFU per gram of fertilizer are allowed [Earth et al. 2008]. The same microbiological analysis were carried out on the sand taken from the town beach as the ones conducted during horticultural substrates checks. The presence of Salmonella bacteria and intestinal parasites eggs was detected, as well as the presence of coliform bacteria including those belonging to the Escherichia coli species, which is a universal indicator of sanitary different environmental matrices and products [Halliday and Gast 2011; Cloutier at al. 2015; Pyz-Łukasik et al. 2015]. Homogeneous material - sand purchased from a local producer of aggregates - was sprinkled on a beach and evenly distributed. This sand powered the area of the volleyball zone and the vicinity of catering and playground zones. Since the functions of sand were diversified through putting it in different zones of the beach, have its microbiological parameters also changed? The aim of the experiment was to assess the effects of different ways of using beach sand to microbiological properties and its health assessment.

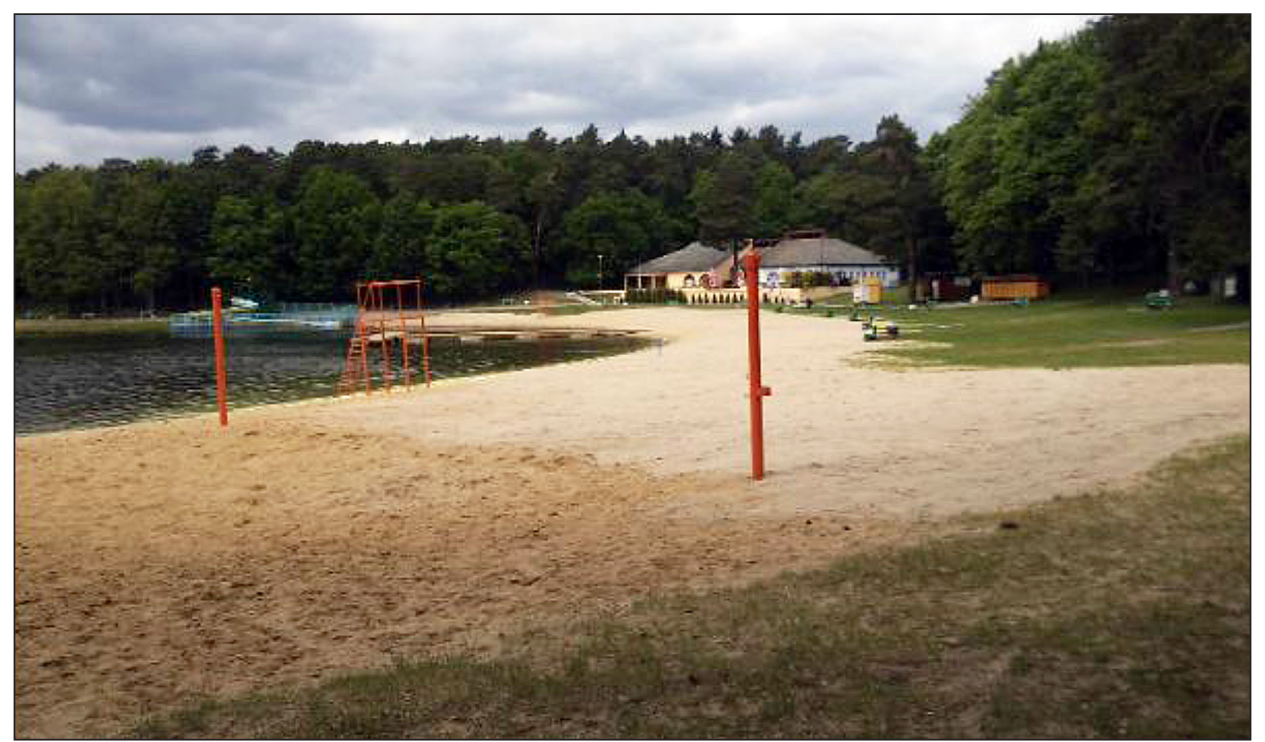

Photo 1. The municipal bathing beach by the Deep lake in Szczecin (27 $7^{\text {th }}$ May, 2015) 


\section{MATERIAL AND METHODS}

The investigations of beach sand were carried out in 2013 from the area of the Szczecin by the Deep lake urban bathing beach (Photo 1). The composite samples of sand were taken from 3 locations (3 objects): volleyball court, children's playground, catering-sanitary zone (vicinity). In every object 3 sites of collecting the samples were selected, spaced approx. 5 meters from one another. 3 samples from every place were taken (repeatedly). As a result, 9 samples of sand from each object in each period of examinations were obtained. The sand samples of these objects were collected in the spring and autumn seasons. The objects were distanced from the shoreline of the lake by approx. 8 meters. In the Regional Chemical-Agricultural Station in Szczecin the content of organic substances (measuring the loss on ignition) and total nitrogen content in the sand were determined (with the Kjeldahl method) [Ostrowska et al. 1991]. For chemical examinations the sand was taken from three objects in three repetitions at the beginning and at the end of experience. Sand in terms of chemical parameters was not diversified, the content of the organic substance was ranged from $1.0-1.5 \mathrm{~g} \cdot \mathrm{kg}^{-1}$ and total nitrogen of $0.2-0.4 \mathrm{~g} \cdot \mathrm{kg}^{-1}$. The sand was taken up from the surface layer at a depth of $1-10 \mathrm{~cm}$ and placed in containers of polypropylene. After being transported to a laboratory the material was sieved through a sieve with an aperture of $2 \mathrm{~mm}$, in order to remove pollutants, moisture was determined by weight of the sand for each sample and microbiological analyses were performed.

Microbiological analyses included:

- Quantification of live heterotrophic bacteria and fungi. Seeding decimal dilutions were performed on soil (sand) by submerged microbiological plate on the ground. A norm PN-EN ISO 6222:2004 was exploited - determination of the total number of colonies by inoculation on nutrient agar (methodology was adapted to the requirements for soil bacteria through the use of Bunt-Roviry substrate[1955] and was adapted to the requirements for fungi by using Martin's substrate [1950].

- Detecting the presence of coliform bacteria. The used methodology is placed in the Polish standard BS-Z-19000-2 Quality of the soil Evaluation of the sanitary state of the soil Detection of the presence and quantification of the presence of coliform bacteria.
- Detecting the presence of Salmonella bacteria. The methodology included in the Polish Norm PN-Z- 19000-1: 2001 Quality of the soil was used - Evaluation of the sanitary state of the soil - Detection of Salmonella bacteria.

- Detection of intestinal parasites eggs of $A s-$ caris lumbricoides and Trichuris trichuria. Methodology was used Polish Norm PN-Z19000-4: 2001 Quality of the soil - Evaluation of the sanitary state of the soil - Detection of intestinal parasites eggs of Ascaris lumbricoides and Trichuris trichiura.

In order to determine statistically significant differences in the number of bacteria and fungi between the objects and the terms of measurements, the analyses of variance and Tukey's multiple comparison test, at a significance level $\alpha=$ 0.05 were used. Before taking statistical analysis, the results were transformed using logarithmic function.

\section{RESULTS AND DISCUSSION}

Sand taken up at the beginning of the recreation season did not differ significantly in relation to all checked parameters irrespective of the place of sampling. In terms of the number of microorganisms there were no statistically significant differences between objects (volleyball court, playground, catering and sanitary zone), also within individual objects (each object taken after 9 samples of sand) in general important differences were not stated (Figure 1). In the initial period of analyses, there was no presence of bacteria of the genus Salmonella, bacteria belonging to the species Escherichia coli, or the presence of parasites eggs. Coliform bacteria in the first term of measurements were present in several samples of each object (Table 1). In the initial period of analyses sand was homogeneous in terms of the studied parameters, since it lied on the beach only for a week. The presence of coliform in several samples of sand may indicate either its incidental contamination during storage and transport, or polluting it while several days' use. One should keep in mind that the coliform bacteria is a wide group of bacteria included in different kinds (Escherichia, Enterobacter, Citrobacter, Klebsiella), which mainly endophytes humans and animals, but are also able to grow in a medium soil bacteria [Doyle and Erickson 2006; Fiello et al. 2014]. Therefore, the presence of coliform bacte- 


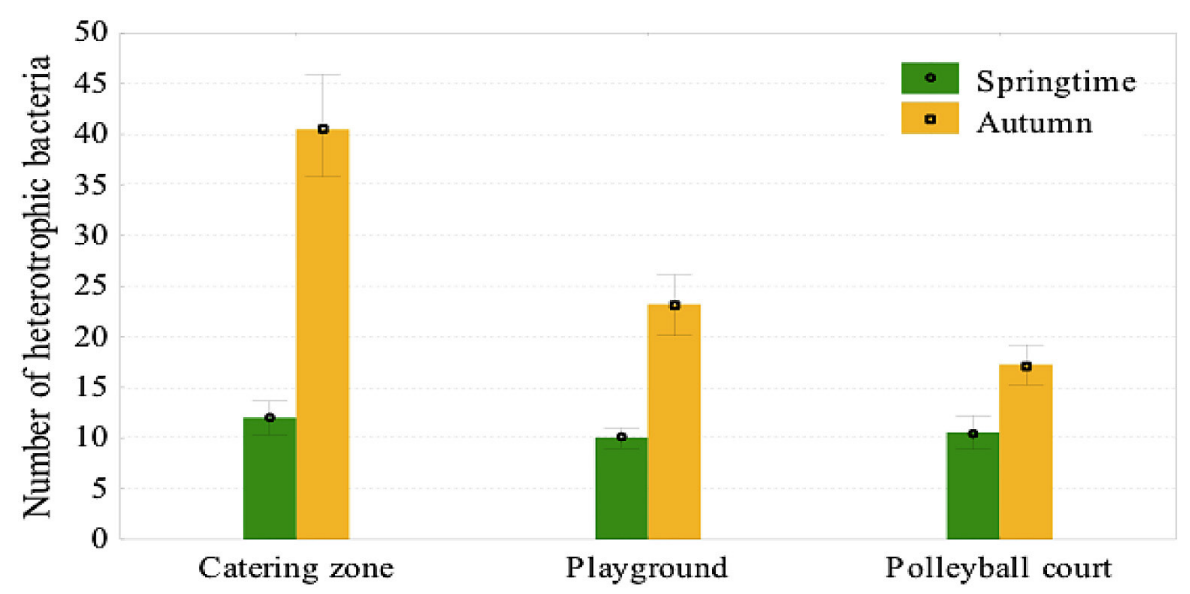

Figure 1. The number of bacteria $\left(\cdot 10^{4} \mathrm{CFU} \cdot \mathrm{g}^{-1}\right)$ in the sand collected from the beach. Symbols in bar graphs the mean averages and standard deviations

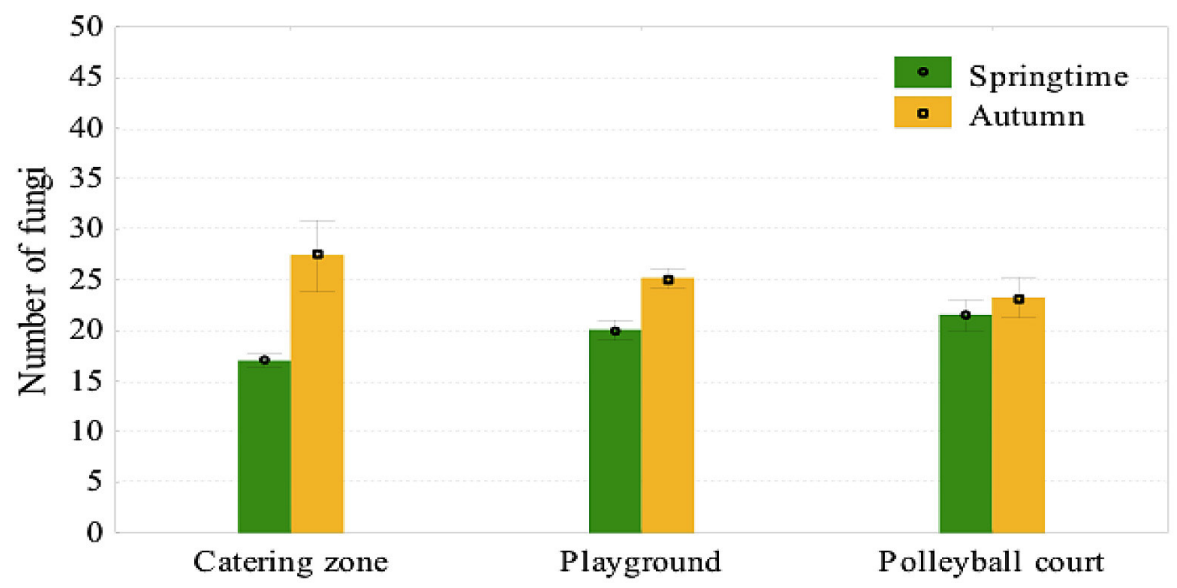

Figure 2. The number of fungi $\left(\cdot 10^{2} \mathrm{CFU} \cdot \mathrm{g}^{-1}\right)$ in the sand collected from the beach. Symbols in bar graphs the mean averages and standard deviations

ria is indicating a potential faecal contamination, however, if amongst identified coliform bacteria there is no typical indicators of $E$. coli, namely means that contamination took place a long time ago - at least a few months ago - or bacteria are present there from a material rich in organic matter [Libudzisz and Kowal 2000; OlańczukNeyman 2003; Drożdżyńska et al. 2013].

In the second period - autumn - the sand was diversified in terms of the studied parameters. It is evident that the samples taken from the area of catering zone contained more heterotrophic bacteria and fungi, compared to other objects, which indicates contamination sand remnants of food and packaging materials (substrates for microorganisms) (Figure 1, 2).

Determining of a lot of samples, more than in the initial period, it was observed that the sand from this zone contained E. coli bacteria, which indicates a contact of sand in this zone with faeces. Intestinal micro-organisms get on the sandy recreation area with the faeces of animals, mainly dogs, cats, rodents and people.

Theoretically, animals have access to the sand on the area of the Szczecin's beach, or the fence is not an obstacle for rodents and cats, but security forces guarding the facility report numerous repeated situations with animals entering the facility. The reason for sand contamination of $E$. coli could also be a neighborhood catering zone and changing rooms, so the source of contamination could be human. The major diseases evoked by the contact of people with polluted sand are caused not through bacteria indicator, and by bacteria of the genus Salmonella that cause salmonellosis; dermatophytic fungus or yeast causing skin and nail fungal infection; intestinal parasites Toxocara canis, Toxocara cati (Toxocara canis and the cat) causing serious toxocariasis; protozoan Toxoplasma gondii - causing toxoplasmosis [Kasper and Fauci 2012]. Fortunately, in the studied material, there was no presence of these 
Table 1. The presence of coliform bacteria and E. coli in the sand taken from the area of the beach

\begin{tabular}{|c|c|c|c|c|}
\hline \multirow{2}{*}{ The object's location } & \multicolumn{2}{|c|}{ Spring } & \multicolumn{2}{|c|}{ Autumn } \\
\hline & Coliform bacteria & E. coli & Coliform bacteria & E. coll \\
\hline \multicolumn{5}{|c|}{ Catering zone (vicinity) } \\
\hline Place 1 & ++- & --- & +++ & +++ \\
\hline Place 2 & --- & --- & +++ & +++ \\
\hline Place 3 & +-- & --- & +++ & +-- \\
\hline \multicolumn{5}{|c|}{ Children's playground } \\
\hline Place 1 & --- & --- & +++ & ++- \\
\hline Place 2 & ++- & --- & ++- & --- \\
\hline Place 3 & +-- & --- & ++- & --- \\
\hline \multicolumn{5}{|c|}{ Volleyball court } \\
\hline Place 1 & --- & --- & +-- & --- \\
\hline Place 2 & +-- & --- & ++- & --- \\
\hline Place 3 & +++ & --- & +-- & --- \\
\hline
\end{tabular}

pathogenic organisms, although the presence of indicator $E$. coli bacteria indicates a contact of sand with the feces, so the presence of these organisms cannot be entirely ruled out (the whole mass of sand was not tested). In two remaining objects the quantitative and qualitative differentiation of the examined microorganisms was lower. However, despite this significant difference was found between the number of bacteria in sand collected from the area of the pitch and playground. Sand from the playground contained more microorganisms. Occasionally (in 2 to 9 samples of sand from the playground) the presence of $E$. coli bacteria was also found. The sand collected from the volleyball pitch did not contain any E. coli bacteria (Table 1).

\section{CONCLUSIONS}

In conclusion, we can say that the same sand used in various ways takes on different microbiological properties. Several months of use of the sand in the area of catering, amusement area and court changed its microbiological parameters. The biggest number of heterotrophic bacteria and fungi and E. coli bacteria indicator occurred in the samples of sand collected from the catering zone. Although cleaning service effectively removed garbage during the summer season, the remains of tiny pieces of food and packaging in the ground could become a substrate for microorganisms, hence a significant increase in their number. The presence of the indicator bacteria in the sand, in particular those belonging to the E. coli spe- cies is a cause for concern, as it is the obvious evidence of faecal contamination of the sand (and so is the probability of the presence of pathogenic organisms). These results indicate the need for a deliberate choice of the location for sunbathing (children's play in the sand).

\section{REFERENCES}

1. Bunt J.S., Rovira A.D. 1955. Microbiological studies of some subantarctic soil. Soil Sci., 6 (1), 119-128.

2. Cloutier D.D., Alm E.W., McLellan S.L. 2015. The influence of land-use, nutrients, and geography on microbial communities and fecal indicator abundance at Lake Michigan beaches. Appl Environ Microbiol, 233-245.

3. Delbeke S., Ceuppens S., Hessel C.T., Castro I., Jacxsens L., De Zutter L., Uyttendaele M. 2015. Microbial safety and sanitary quality of strawberry primary production in Belgium: risk factors for Salmonella and Shigella toxin-producing Escherichia coli contamination. Appl Environ Microbiol., 81(7), 2562-2570.

4. Doyle M.P., Erickson M.C. 2006. Closing the door on the fecal coliform assay. Microbe, 1, 162-163.

5. Drożdżyńska A., Pawlicka J., Czaczyk K. 2012. Charakterystyka i perspektywy wykorzystania $\mathrm{Ci}$ trobacter spp. NIT, 3(6), 22-36.

6. Earth J., Amlinger F., Favoino E., Siebert S., Kehres B., Gottschall R., Bieker M., Lobig A., Bidlingmaier W. 2008. Raport końcowy Komisji Europejskiej „Produkcja i użycie kompostu w UE”. DG Wspólne Centrum Badawcze/IPST.

7. Fiello M., Mikell A.T., Moore M.T., Cooper C.M. 2014. Variability in the characterization of total coliforms, fecal coliforms and Escherichia coli in rec- 
reational water supplies of north Mississippi, USA. Bull Environ Contam Toxicol., 93(2), 133-137.

8. Halliday E., Gast R.J. 2011. Bacteria in beach sands: an emerging challenge in protecting coastal water quality and bather health. Environ Sci Technol. 45(2), 370-379.

9. Kasper D.L., Fauci A.S., Flisiak R (red. wyd. pol.). 2012. Harrison, Choroby zakaźne. Tom 1, 2. Wyd. Czelej Lublin.

10. Kukwa A. 2012. Czy jesteśmy bezpieczni na plaży? Wirtualna Polska. Wp.pl. Dostęp z dnia 28.05.2015. http://odkrywcy.pl/kat,111396,title,Czy-jestesmybezpieczni-na-plazy,wid,14550083,wiadomosc. html\#czytajdalej

11. Libudzisz Z., Kowal K. 2000. Mikrobiologia Techniczna. Tom I. Wyd. PŁ Łódź.

12. Martin J.P., 1950. Use of acid, Rose Bengales and Streptomycin in the plate method for estimting soil fungi. Soil Sci. 69, 215-233.

13. Młotkowska J. 2014. Sanepid zbadał piaskownice. Dużo w nich pasożytów. Wyborcza pl. Dostęp z dnia 28.05.2015. http://olsztyn.gazeta.pl/olsztyn/1,48726,16347203,Sanepid_zbadal_piaskownice_Duzo_w_nini_pasozytow.html

14. Olańczuk-Neyman K. 2003. Mikrobiologiczne aspekty odprowadzania ścieków do przybrzeżnych wód morskich. Inż. Mors. Geotech., 2, 55-62.

15. Ostrowska A., Gawliński S., Szczubiałka Z., 1991. Metody analizy i oceny właściwości gleb i roślin.
Wyd. IOŚ, Warszawa.

16. Polska Norma PN-EN ISO 6222:2004 - Określanie ogólnej liczby kolonii metodą posiewu na agarze odżywczym.

17. Polska Norma PN-Z-19000-1:2001 Jakość gleby Ocena stanu sanitarnego gleby - Wykrywanie bakterii z rodzaju Salmonella.

18. Polska Norma PN-Z-19000-4:2001 Jakość gleby Ocena stanu sanitarnego gleby - Wykrywanie jaj pasożytów jelitowych Ascaris lumbricoides $i$ Trichuris trichiura.

19. Polska Norma PN-Z-19000-2 Jakość gleby - Ocena stanu sanitarnego gleby - Wykrywanie obecności i oznaczanie ilościowe bakterii z grupy coli.

20. Pyz-Łukasik R., Paszkiewicz W., Tatara M.R., Brodzki P., Bełkot Z. 2015. Microbiological quality of milk sold directly from producers to consumers. J Dairy Sci. 15, 299-234.

21. Rozporządzenie Ministra Rolnictwa i Rozwoju Wsi z dnia 18 czerwca 2008 r. w sprawie wykonania niektórych przepisów ustawy o nawozach i nawożeniu (Dz. U. 2008 nr 119 poz. 765).

22. Rozporządzenie Ministra Zdrowia z dnia 8 kwietnia 2011 r. w sprawie prowadzenia nadzoru nad jakością wody w kąpielisku i miejscu wykorzystywanym do kąpieli (Dz. U. 2011 nr 86 poz. 478).

23. Żakowska Z., Stobińska H. 2000. Mikrobiologia i higiena w przemyśle spożywczym. Wyd. WPŁ Łódź. 